\title{
Inter-element Effects in the Determination of Trace Amounts of Plutonium by High Resolution Inductively Coupled Plasma Atomic Emission Spectrometry
}

\author{
S.K. Thulasidas , V.C. Adya, Mithlesh Kumar, T.K. Seshagiri*, and S.V. Godbole \\ Radiochemistry Division, Bhabha Atomic Research Centre \\ Trombay, Mumbai - 400 085, India
}

\section{INTRODUCTION}

Plutonium $(\mathrm{Pu})$ is a highly toxic, fissionable element that is used for power generation in nuclear reactors. Since plutonium is produced in large amounts during the operation of nuclear power plants, it is essential for public health and nuclear safeguards to develop sensitive, accurate, and rapid analytical methods for the determination of $\mathrm{Pu}$ in the nuclear fuel cycle program. The recovery of $\mathrm{Pu}$ and uranium (U) from all types of scraps and residues, as well as the removal of $\mathrm{Pu}$ and other trans-uranic elements from radioactive wastes, are highly pressing problems from an economical and ecological point of view. Determination of $\mathrm{Pu}$ at trace levels is of utmost importance in the assay of waste solutions generated in radiochemical laboratories. It is also imperative to monitor the trace quantities of Pu left in the raffinate after extraction of $\mathrm{Pu}$ by suitable chemical separation procedures. The presence of significant amounts of $\mathrm{Pu}$ in view of its complex spectra can cause spectral interferences resulting in the overestimation of the analytes of interest. Thus, determination of $\mathrm{Pu}$ at trace levels in aqueous solutions is an important aspect of the nuclear fuel cycle. The methods of $\alpha$-counting, $\gamma$-spectrometry, inductively coupled plasma atomic emission spectrometry (ICP-AES), and isotope dilution mass spectrometry (ID-MS) have been used in the

*Corresponding author.

E-mail: giritks@gmail.com

\section{ABSTRACT}

An analytical method was developed for the determination of plutonium $(\mathrm{Pu})$ in aqueous solutions using high resolution inductively coupled plasma atomic emission spectrometry (ICP-AES). The analytical range for $\mathrm{Pu}$ in aqueous solution was 0.1 to $100 \mu \mathrm{g} / \mathrm{mL}$. The validity of the method was established by analysis of several synthetic samples of plutonium. Plutonium was estimated in synthetic samples in the presence of uranium, thorium, rare earths, and common metallic elements after applying inter-elemental correction factors for the interfering elements. Radiometric methods were employed for an independent cross-check of the values obtained by ICP-AES.

The results obtained by ICPAES and the radiometric method were in good agreement with a precision of 10 to $20 \%$ at very low concentrations of $\mathrm{Pu}$ and better than 5\% at higher concentration levels.

The method is useful for the determination of $\mathrm{Pu}$ in different types of aqueous waste solutions generated in radiochemical laboratories, and also to monitor the trace levels of Pu left in the raffinate after its chemical separation along with other metallic constituents. It should be noted that the presence of large amounts of $\mathrm{Pu}$ in the raffinate can lead to an over-estimate in measured concentrations of the analytes of interest due to its rich emission spectrum. nuclear industry for monitoring the $\mathrm{Pu}$ content. The relative sensitivities (1) of these techniques are listed in Table I. Fast and reliable methods for the determination of plutonium (Pu), uranium (U), and thorium (Th) in samples are ICPAES and $\alpha$-counting. However, when samples contain large concentrations of elements having rich emission spectra (such as uranium, rare earths, thorium, etc.), chemical separation of these interfering elements would be required prior to ICP-AES analysis. ICP-AES has been successfully employed for the determination of common metallic elements and rare earths in a variety of nuclear fuels of interest (2-7). To our knowledge, only a few reports (8-12) have been published using ICP-AES for the determination of Pu. The simultaneous determination of americium (Am) and plutonium by ICP-AES has been reported by Claudon et. al. (11). A comparison of instrumental methods used in the determination of $\mathrm{U}$ and $\mathrm{Pu}$ has been reported by Carmen Sabau et. al. (13).

The aqueous solution generated in a reprocessing plant contains traces of plutonium, uranium, fission products, and other common metallic elements such as $\mathrm{Fe}, \mathrm{Ni}$, $\mathrm{Cr}, \mathrm{Mn}$, etc. In addition, Advanced Heavy Water Reactor (AHWR) fuels that will be used in the future are based on the combination of Th with other co-contaminants such as (Th-Pu) and (Th-U). This necessitates the development of a method to determine $\mathrm{Pu}$ in the presence of other co-contaminants. 
In this paper, an analytical method has been developed for the determination of $\mathrm{Pu}$ in an aqueous medium as well as in the presence of uranium, thorium, rare earths, and certain common metallic constituents using high resolution ICPAES spectrometry.

\section{EXPERIMENTAL}

\section{Instrumentation}

The instruments used in the present studies was a Jobin Yvon Ultima ICP-AES (Longjumeau Cedex, France), equipped with an R.F. generator at a frequency of

TABLE I

Relative Sensitivities of Different Techniques for Pu Determination

\begin{tabular}{lr}
\hline Techniques & \\
\hline$\alpha$-spectrometry & $1 \mathrm{pg}$ \\
$\gamma$-spectrometry & $\mu \mathrm{g} / \mathrm{mg}$ \\
Inductively coupled plasma & \\
$\quad$ mass spectrometry (ICP-MS) & $<1000 \mathrm{fg}$ \\
Inductively coupled plasma & \\
$\quad$ atomic emission spectrometry (ICP-AES) & $15 \mathrm{ng}$ \\
ICP laser-excited atomic fluorescence & \\
$\quad$ spectrometry (LEAFS) & $50-500 \mathrm{ng}$ \\
Coulometry & $200 \mathrm{pg}$ \\
Titrimetry & $1-100 \mathrm{mg}$ \\
\hline
\end{tabular}

TABLE II ICP-AES Instrumental Operating Conditions

\begin{tabular}{ll} 
Model & Ultima ICP-AES \\
Focal Length & $1 \mathrm{M}$ \\
Grating & Two holographic gratings with 4320 \\
& grooves/mm and 2400 grooves/mm \\
Range Covered & (a) $180-450 \mathrm{~nm}$; (b) $400-800 \mathrm{~nm}$ \\
R.F. Generator Frequency & $40.68 \mathrm{MHz}$ \\
Forward Power & $1.0 \mathrm{KW}$ \\
Reflected Power & $<10 \mathrm{~W}$ \\
Nebulizer & Meinhard TR $50-\mathrm{C} 1$ glass \\
Pressure Input & 3 bars \\
Spray Chamber & Cyclonic \\
Plasma Torch & Demountable torch assembly with \\
& three co-axial concentric tubes; \\
& central injector of alumina and \\
two quartz tubes \\
Argon Plasma Gas Flow & $12 \mathrm{~L} / \mathrm{min}$ \\
Cooling gas flow & $0.2 \mathrm{~L} / \mathrm{min}$ \\
Nebulizer Pressure & 3 bars \\
Nebulizer flow & $0.85 \mathrm{~L} / \mathrm{min}$ \\
Pressure of the Manometer & 6 bar \\
Pump Speed & $20 \mathrm{rotations} / \mathrm{min}$ \\
Sample Uptake Rate & $1 \mathrm{~mL} / \mathrm{min}$ \\
\hline
\end{tabular}

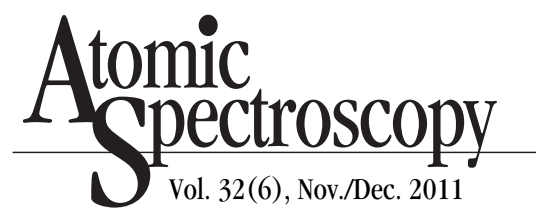

40.68 MHz. The monochromator consisted of two holographic gratings with 4320 grooves $/ \mathrm{mm}$ and 2400 grooves/mm covering different range with back-to-back vertical fitting. The sample introduction system had a Meinhard ${ }^{\circledR}$ TR 50-C1 glass nebulizer and a cyclonic spray chamber. The instrumental operating conditions are listed in Table II.

\section{Standard Solutions and Reagents}

A 100-mg amount of preanalyzed $\mathrm{PuO}_{2}$ was dissolved in a mixed acid of concentrated $\mathrm{HNO}_{3}+0.35 \mathrm{M} \mathrm{HF}$ which was evaporated to near dryness. Then, $4 \mathrm{M}$ $\mathrm{HNO}_{3}$ was added to the residual solution. This step was repeated three times to ensure removal of HF. This solution was diluted in $10 \mathrm{~mL}$ of $4 \mathrm{M} \mathrm{HNO}_{3}$ to obtain a $\mathrm{Pu}$ standard of $10 \mathrm{mg} / \mathrm{mL}$ concentration. The standard solution was subsequently employed to prepare a series of $\mathrm{Pu}$ solutions in the 0.02 to $100 \mu \mathrm{g} / \mathrm{mL}$ concentration range after appropriate dilution.

The reagents used in the preparation of the standards and samples were of electronic grade purity. The water used was doubly distilled in a quartz apparatus prior to its use.

\section{Synthetic Samples}

To gain confidence in the determination of plutonium, nine synthetic samples at different $\mathrm{Pu}$ concentrations were prepared and analyzed by the standardized procedure. Several of these synthetic samples were also analyzed by radiometric methods to ascertain the $\mathrm{Pu}$ concentration. Appropriate dilutions were used in the radiometric techniques to obtain the net counts within the range of the detector employed. Corrections for the ${ }^{241} \mathrm{Am}$ concentration were also performed by monitoring with gamma spectrometry. 
Our earlier studies show $(5,14)$ that $\mathrm{Pu}$ concentrations of $<25 \mu \mathrm{g} / \mathrm{mL}$ do not significantly contribute to the preferred analytical wavelengths for the common elements $\mathrm{Al}, \mathrm{Ag}, \mathrm{B}$, $\mathrm{Ca}, \mathrm{Cd}, \mathrm{Co}, \mathrm{Cr}, \mathrm{Cu}, \mathrm{Fe}, \mathrm{Ga}, \mathrm{Mg}, \mathrm{Mn}$, $\mathrm{Na}, \mathrm{Ni}, \mathrm{Pb}, \mathrm{Sr}, \mathrm{Zn}$, and the rare earths Ce, Dy, Eu, Gd, Sm, and Tm. Hence, most of the interference studies in the present work were carried out with $10 \mu \mathrm{g} / \mathrm{mL} \mathrm{Pu}$. To study the effect of uranium, thorium, and rare earths (known for their rich emission spectrum) on the determination of $\mathrm{Pu}$, spiked samples having a $10-\mu \mathrm{g} / \mathrm{mL}$ Pu concentration along with varying concentrations of concomitant elements at different Pu:concomitant element concentration ratios of 1:0, $1: 1,1: 5$, and 1:10 were prepared. The effect of the common metallic concomitants (Al, Ag, B, Ca, Cd, $\mathrm{Co}, \mathrm{Cr}, \mathrm{Cu}, \mathrm{Fe}, \mathrm{Ga}, \mathrm{Mg}, \mathrm{Mn}, \mathrm{Na}, \mathrm{Ni}$, $\mathrm{Pb}, \mathrm{Sr}$, and $\mathrm{Zn}$ ) on Pu estimation was also investigated. This was done by spiking a $10-\mu \mathrm{g} / \mathrm{mL} \mathrm{Pu}$ concentration with 10,50 , and $100 \mu \mathrm{g} / \mathrm{mL}$ each of an E. Merck standard (Darmstadt, Germany) for each of the above elements. The standard containing these concomitants at $1 \mathrm{mg} / \mathrm{mL}$ was appropriately diluted with $1 \mathrm{M} \mathrm{HNO}_{3}$ to obtain standards with varying concentrations of these elements. The concentration of each standard was confirmed using ICP-AES analysis.

\section{PROCEDURE}

A detailed spectral scan for the ICP plutonium lines ranging from 250-500 nm was carried out by aspirating $25 \mu \mathrm{g} / \mathrm{mL} \mathrm{Pu}$ into the plasma. Feasibility studies were carried out at five $\mathrm{Pu}$ wavelengths (296.464, 300.057, 340.110, 363.221 , and $453.615 \mathrm{~nm})$ as reported in the literature $(8,10)$. The instrumental parameters were optimized for positioning of the analytical line with appropriate sensitivity on the photomultiplier tube. The Pu lines at $300.057 \mathrm{~nm}$ and $453.615 \mathrm{~nm}$ were selected since they provided the optimum signalto-noise ratio. With our instrument, a four point standardization containing $\mathrm{Pu}$ concentrations of 0.2 , 10,50 , and $100 \mu \mathrm{g} / \mathrm{mL}$ was employed to obtain the calibration curve for the two analytical Pu lines. The calibration curves obtained for the $\mathrm{Pu}$ lines at 300.057 and 453.615 $\mathrm{nm}$ are shown in Figure 1.
Analysis of the standards was carried out to determine the precision and accuracy of Pu determination. For all Pu standards, eight replicate measurements were performed. The slope and intercept for the calibration curves along with error bars for $\mathrm{Pu}(300.057$ and $453.615 \mathrm{~nm}$ ) are included as an insert in Figure 1. A series of spiked samples was analyzed to study the possible inter-element effects. The $\mathrm{Pu}$ content in the presence of the interferents was monitored using the two Pu analytical lines mentioned above. Inter-element correction factors were evaluated by aspirating $500 \mu \mathrm{g} / \mathrm{mL}$ of the individual elemental SpecPure ${ }^{\circledR}$ solutions of $\mathrm{Co}, \mathrm{Cr}, \mathrm{Cu}, \mathrm{Fe}, \mathrm{Mn}, \mathrm{Ni}, \mathrm{Dy}$, $\mathrm{Eu}, \mathrm{Gd}, \mathrm{Sm}$, Th, and U into the ICPAES. Figure 2 shows typical spectral profiles at $300.057 \mathrm{~nm}$ of:

(a) $10 \mu \mathrm{g} / \mathrm{mL} \mathrm{Pu}+$ E. Merck multielemental standard (common impurity mixture (CIM) containing $\mathrm{Al}$, $\mathrm{Ca}, \mathrm{Co}, \mathrm{Cd}, \mathrm{Cr}, \mathrm{Cu}, \mathrm{Fe}, \mathrm{Mg}, \mathrm{Mn}$, $\mathrm{Na}, \mathrm{Ni}$, and $\mathrm{Pb}$ each at $10 \mu \mathrm{g} / \mathrm{mL}$; (b) $10 \mu \mathrm{g} / \mathrm{mL} \mathrm{Pu}+50 \mu \mathrm{g} / \mathrm{mL}$ of CIM; and (c) $10 \mu \mathrm{g} / \mathrm{mL} \mathrm{Pu}+$ $100 \mu \mathrm{g} / \mathrm{mL}$ CIM; (d) $10 \mu \mathrm{g} / \mathrm{mL} \mathrm{Pu}$.

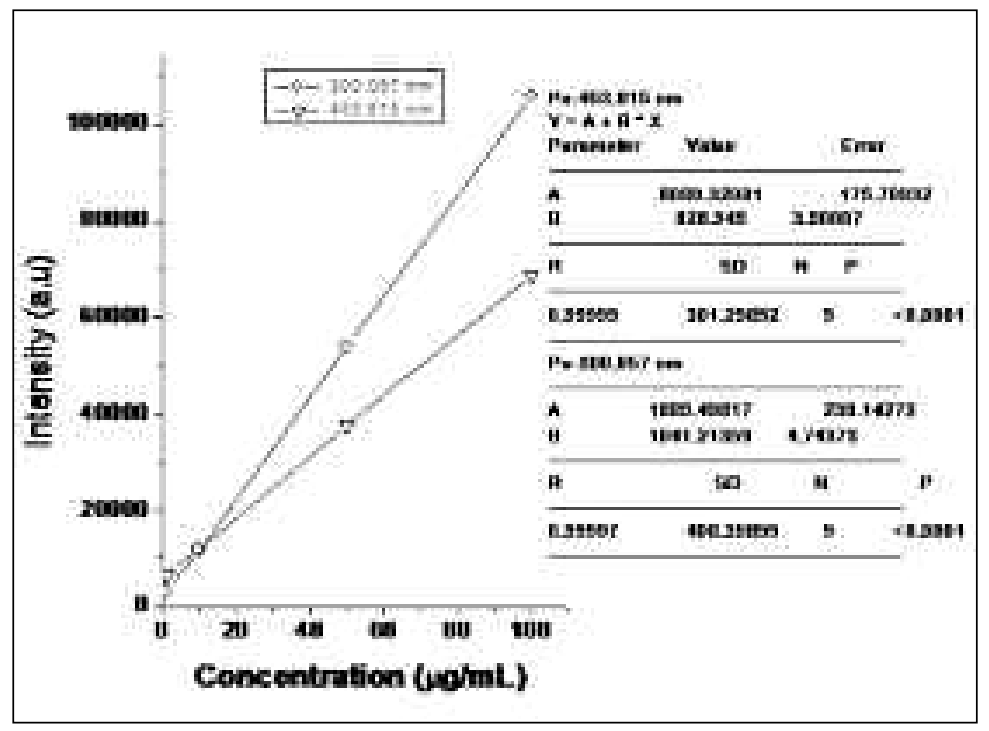

Fig. 1. Calibration curve for Pu $(300.057 \mathrm{~nm})$ and Pu $(453.615 \mathrm{~nm})$.

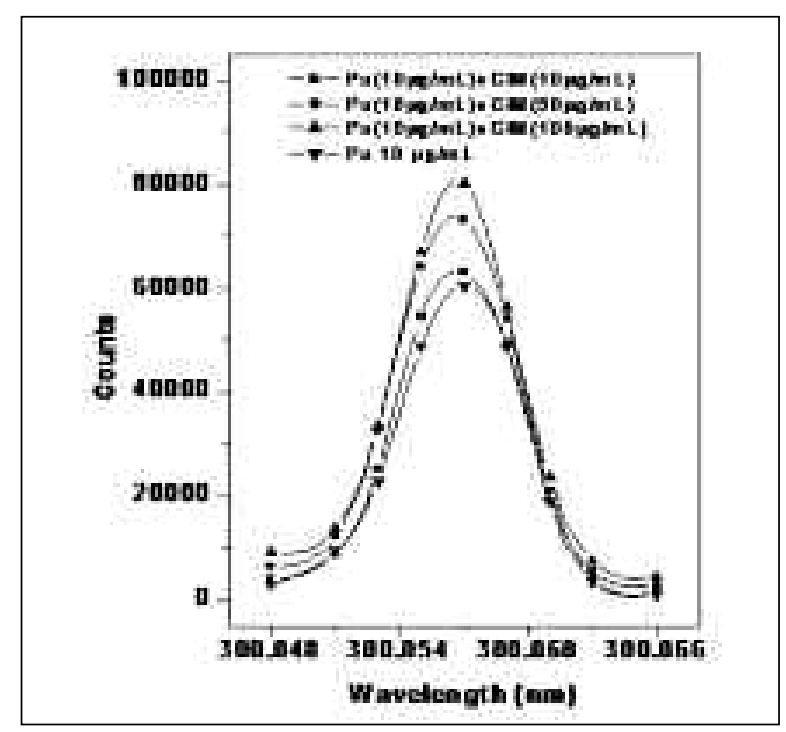

Fig. 2. Profiles for Pu at $300.057 \mathrm{~nm}$ in absence and in presence of varying common metallic impurity elements CIM : Common elements impurity mixture. 
Figure 3 shows the profiles obtained at $300.057 \mathrm{~nm}$ for $10 \mu \mathrm{g} / \mathrm{mL} \mathrm{Pu}$ and a mixture of $\mathrm{Pu}$ and rare earths in (a) $\mathrm{Pu}(10 \mu \mathrm{g} / \mathrm{mL})$ $+\operatorname{REE}(10 \mu \mathrm{g} / \mathrm{mL})$, (b)Pu $(10 \mu \mathrm{g} / \mathrm{mL})$ $+\operatorname{REE}(50 \mu \mathrm{g} / \mathrm{mL})$, (c) Pu $(10 \mu \mathrm{g} / \mathrm{mL})$ $+\operatorname{REE}(100 \mu \mathrm{g} / \mathrm{mL})$, (d) Pu $(10 \mu \mathrm{g} / \mathrm{mL})$. As can be seen from Figures 2 and 3 , there is a marginal increase in the background and a significant spurious increase in the peak intensity above the 1:5 ratio for the common elements (Al, Ca, Co, Cd, Cr, $\mathrm{Cu}, \mathrm{Fe}, \mathrm{Mg}, \mathrm{Mn}, \mathrm{Na}, \mathrm{Ni}$, and $\mathrm{Pb}$ ) and the rare earth elements (Ce, Dy, Eu, $\mathrm{Gd}, \mathrm{Sm}$, and Tm) above the 1:10 ratio. Similar features were observed for the $\mathrm{Pu}$ line at $453.615 \mathrm{~nm}$, except that the effect is more pronounced for the rare earths above the 1:5 ratio ( $\mathrm{Pu}: \mathrm{REE})$, while for common elements it was above the 1:10 ratio (Pu:CIM). Uranium and thorium also exhibit similar trends in their spectral profiles.

The analytical range obtained in aqueous solution was 0.1-100.0 $\mu \mathrm{g} / \mathrm{mL}$ for Pu at $300.057 \mathrm{~nm}$; for $453.615 \mathrm{~nm}$, it was $0.2-100 \mu \mathrm{g} / \mathrm{mL}$. The detection limit calculated as

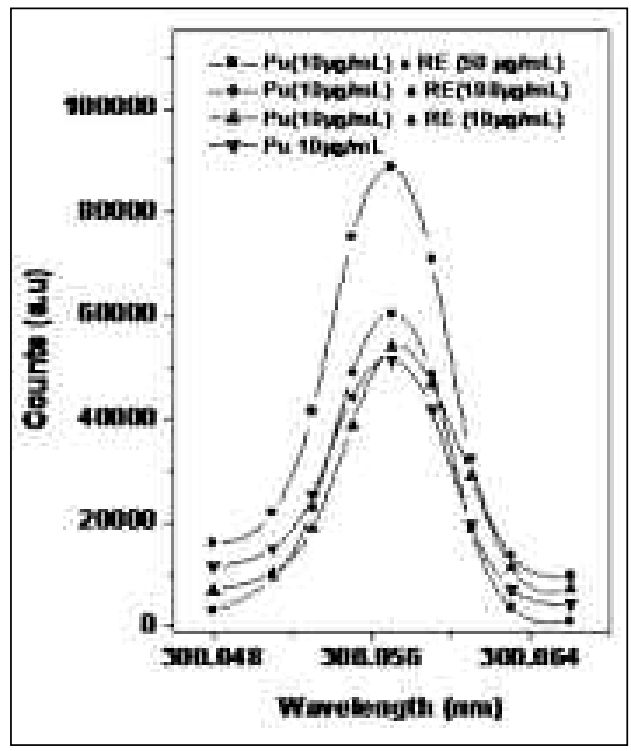

Fig. 3. Profiles for Pu at $300.057 \mathrm{~nm}$ in absence and in presence of varying rare earth impuritie elements. REE: Rare earths the concentration corresponding to a signal equal to the blank signal plus three times its standard deviation (15) was $30 \mu \mathrm{g} / \mathrm{L}$ for $\mathrm{Pu}$ at $300.057 \mathrm{~nm}$ and $70 \mu \mathrm{g} / \mathrm{L}$ for Pu at $453.615 \mathrm{~nm}$.

A comparison of the detection limits obtained for Pu by different workers is given in Table III. The limits obtained in the present studies are better than those reported by Edelson et al. (8), Kulkarni et al. (12), and Claudon et al. (11), but comparable to those reported by Manika et al. (9) and Huff and Bowers (10). Observed differences are very likely due to variations in the optical systems and the experimental excitation conditions.

Table IV lists the estimates (based on eight replicate measurements) obtained for $\mathrm{Pu}$ in nine synthetic samples without the presence

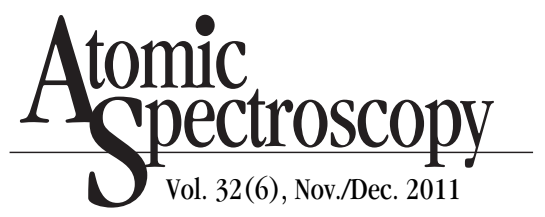

of any concomitant interfering elements. There is close agreement between the Pu amount expected and determined in the present studies. The variation is between 3-6\% at $\mathrm{Pu}$ concentrations ranging from $10-100 \mu \mathrm{g} / \mathrm{mL}$; though the variation was $10 \%$ at the lower concentration of $1 \mu \mathrm{g} / \mathrm{mL}$.

\section{SPECTRAL INTERFERENCE STUDIES}

It is well known that transitional elements, rare earths, thorium, and uranium have complex spectra (rich emission lines) and the presence of spectral lines in the close vicinity of the chosen analytical line can cause an over-estimate of the analytes of interest. This is also reflected in the spectral profile studies of the Pu lines at 300.057 and $453.615 \mathrm{~nm}$ for different sets

TABLE III

Plutonium Detection Limits $(\mu \mathrm{g} / \mathrm{L})$

\begin{tabular}{ccccccc}
\hline$\lambda(\mathrm{nm})$ & Present* & $\begin{array}{c}\text { (Ref. 12) } \\
\text { (Kulkarni) } \\
(1990)\end{array}$ & $\begin{array}{c}\text { (Ref. 8) } \\
\text { (Edelson) } \\
(1986)\end{array}$ & $\begin{array}{c}\text { (Ref. 11) } \\
\text { (Claudon) } \\
(1987)\end{array}$ & $\begin{array}{c}\text { (Ref. 10) } \\
\text { (Huff) } \\
(1990)\end{array}$ & $\begin{array}{c}\text { (Ref. 9) } \\
\text { (Mainka) } \\
(1983)\end{array}$ \\
\hline 300.057 & 30 & 200 & 54 & 100 & 28 & 20 \\
453.615 & 70 & 100 & 15 & 220 & 89 & $\begin{array}{c}\text { Not } \\
\text { Reported }\end{array}$ \\
\hline
\end{tabular}

* Based on the formula: Concentration corresponding to analytical signal $=$ $\mathrm{Xbl}+3 \mathrm{Sbl}$, where $\mathrm{Xbl}=$ average signal for blank; $\mathrm{Sbl}=$ standard deviation in the determination of blank.

TABLE IV

Analytical Results for the Determination of Plutonium in Synthetic Samples

\begin{tabular}{ccc}
\hline $\begin{array}{c}\text { Analysis of Synthetic Samples } \\
\text { (conc. in } \mu \mathrm{g} / \mathrm{mL})\end{array}$ & $\begin{array}{c}\text { at } 300.057 \mathrm{~nm} \\
\text { (conc. in } \mu \mathrm{g} / \mathrm{mL})\end{array}$ & $\begin{array}{c}\text { at } 453.615 \mathrm{~nm} \\
\text { (conc. in } \mu \mathrm{g} / \mathrm{mL})\end{array}$ \\
\hline 0.2 & $0.21 \pm 0.02$ & $0.24 \pm 0.02$ \\
0.5 & $0.50 \pm 0.03$ & $0.54 \pm 0.03$ \\
1.0 & $1.1 \pm 0.08$ & $1.3 \pm 0.10$ \\
2.0 & $2.1 \pm 0.09$ & $2.0 \pm 0.05$ \\
10.0 & $10.3 \pm 0.60$ & $9.6 \pm 0.40$ \\
25.0 & $25.4 \pm 1.10$ & $24.2 \pm 1.01$ \\
50.0 & $53.0 \pm 2.31$ & $54.9 \pm 2.01$ \\
100 & $105.4 \pm 4.10$ & $104.0 \pm 3.50$ \\
250 & $254.0 \pm 8.51$ & $252.0 \pm 7.00$ \\
\hline
\end{tabular}


of elements. In the present studies, close to the $\mathrm{Pu}$ line at $300.057 \mathrm{~nm}$ there are spectral lines of the elements $\mathrm{Fe}, \mathrm{Co}, \mathrm{Cr}, \mathrm{Zr}$, and $\mathrm{U}$ in the vicinity of $\pm 0.032 \mathrm{~nm}$. Similarly, in the $\mathrm{Pu}$ line at $453.615 \mathrm{~nm}$, there are spectral lines of Dy, Sm, U, Ti, Fe, and Ce in the vicinity of $\pm 0.030 \mathrm{~nm}$. The presence of these elements in large amounts can result in erroneous values in the measured $\mathrm{Pu}$ concentration.

Spectral interferences can be corrected by determining the correction factor of each element and its concentration during the analytical run. This was done by aspirating
$500 \mu \mathrm{g} / \mathrm{mL}$ of individual solutions of $\mathrm{Co}, \mathrm{Fe}, \mathrm{Cr}, \mathrm{Ni}, \mathrm{Ce}, \mathrm{Dy}, \mathrm{Gd}, \mathrm{Sm}$, $\mathrm{Th}$, and $\mathrm{Zr}$ to the ICP-AES to determine the contribution to the $\mathrm{Pu}$ signal at each of the two chosen analytical $\mathrm{Pu}$ lines. For instance, a $500-\mu \mathrm{g} / \mathrm{mL} \mathrm{U}$ solution gave a contribution of $11.0 \mu \mathrm{g} / \mathrm{mL}$ for $\mathrm{Pu}$ at $300.057 \mathrm{~nm}$ and $6.5 \mu \mathrm{g} / \mathrm{mL}$ for $\mathrm{Pu}$ at $453.615 \mathrm{~nm}$. This would effectively imply a contribution of $0.022 \mu \mathrm{g}$ and $0.013 \mu \mathrm{g}$ per $\mu \mathrm{g}$ of $\mathrm{U}$ for the two analytical lines of $\mathrm{Pu}$ at 300.0567 and $453.615 \mathrm{~nm}$, respectively. The relevant correction factors obtained for the two $\mathrm{Pu}$ analytical lines for the various ele-

TABLE V

Inter-element Correction Factors for Plutonium

\begin{tabular}{cccccc}
\hline $\begin{array}{c}\text { Element } \\
(\text { per } \mu \mathrm{g})\end{array}$ & \multicolumn{2}{c}{$\begin{array}{c}\text { Correction Factor } \\
\text { for Pu }\end{array}$} & $\begin{array}{c}\text { Element } \\
(\text { per } \mu \mathrm{g})\end{array}$ & \multicolumn{2}{c}{$\begin{array}{c}\text { Correction Factor } \\
\text { for Pu }\end{array}$} \\
\hline & $300.057 \mathrm{~nm}$ & $453.615 \mathrm{~nm}$ & & $300.057 \mathrm{~nm}$ & $453.615 \mathrm{~nm}$ \\
\hline $\mathrm{Co}$ & 0.0076 & 0.0003 & $\mathrm{Dy}$ & 0.0039 & 0.0072 \\
$\mathrm{Cr}$ & 0.0011 & 0.0000 & $\mathrm{Ce}$ & 0.0018 & 0.0012 \\
$\mathrm{Fe}$ & 0.0190 & 0.0004 & $\mathrm{Gd}$ & 0.0000 & 0.0052 \\
$\mathrm{Mn}$ & 0.0005 & 0.0000 & $\mathrm{Sm}$ & $0 . / 0007$ & 0.0085 \\
$\mathrm{Ni}$ & 0.0105 & 0.0000 & $\mathrm{Th}$ & 0.0260 & 0.0080 \\
$\mathrm{U}$ & 0.0220 & 0.0130 & $\mathrm{Zr}$ & 0.0006 & 0.0007 \\
\hline
\end{tabular}

TABLE VI

Effect of Common Impurities (Com. Imp.), U, Th, and Rare Earths on the Determination of Pu at $10 \mu \mathrm{g} / \mathrm{mL}$ Concentration

Concentration of

Interfering Element
Concentration of Pu Determined at: $300.057 \mathrm{~nm}$
$453.615 \mathrm{~nm}$

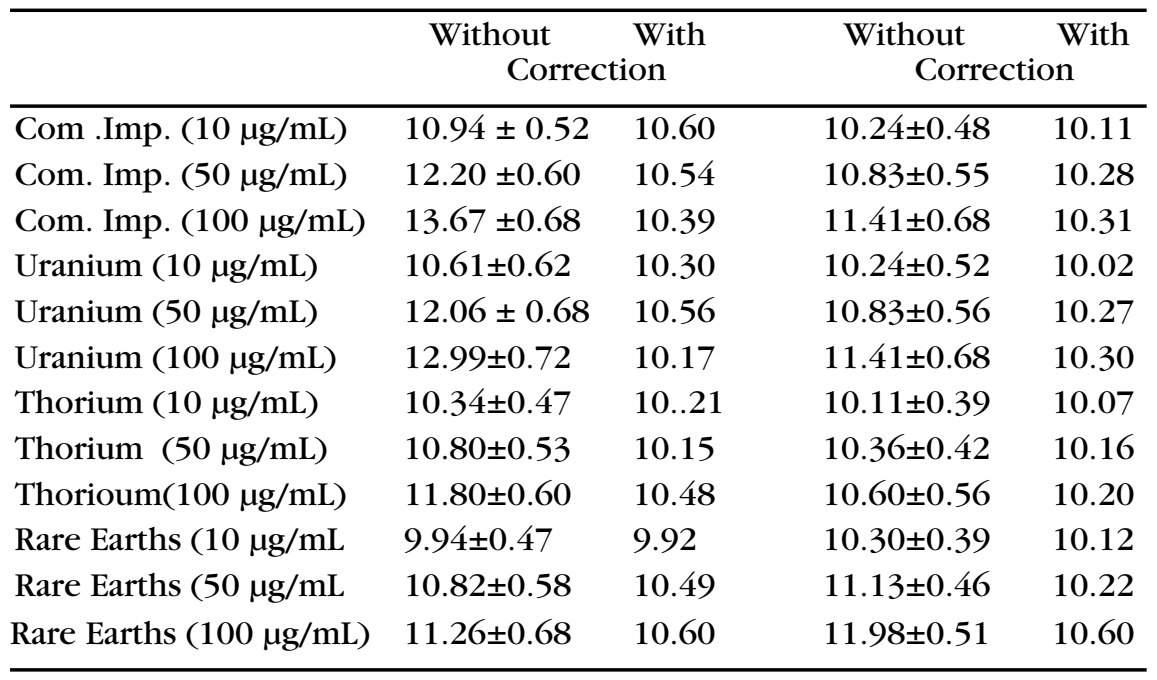

ments are listed in Table V. It is clear from this table that $\mathrm{Pu}$ at the $300.057-\mathrm{nm}$ line is less affected by rare earths but more by common metallic elements, whereas for the $\mathrm{Pu}$ analytical line of $453.615 \mathrm{~nm}$, the reverse is true.

The results of three synthetic samples containing $10 \mu \mathrm{g} / \mathrm{mL} \mathrm{Pu}$ with varying concentrations of the interfering elements are given in Table VI. The agreement between the added and estimated amount is within $8 \%$. Claudon et al. determined Am and Pu by ICP-AES simultaneously and also investigated the effect of $\mathrm{U}$ on $\mathrm{Pu}$ determination (11). Their results indicated that the 453.6-nm line of $\mathrm{Pu}$ was free from interference (error $<5 \%$ ) due to the presence of $U$ at 10 times that of $\mathrm{Pu}$, while the $300.057-\mathrm{nm}$ line caused an error of $10-15 \%$. The results reported in our work (Table VI) clearly indicate that the values are within $8 \%$ once inter-element corrections are applied. However, if $\mathrm{Pu}$ at trace levels is to be determined in samples containing $\geq 0.005 \%$ of $\mathrm{U}$ and $\mathrm{Th}$, the ICP-AES method would have limitations in view of the complex spectra exhibited by these interfering refractory elements and, thus, prior separation of uranium/thorium would have to be applied. Based on the two lines chosen for $\mathrm{Pu}$ in this study, the 453.615-nm line was seen to be less prone to interference effects as compared to the $\mathrm{Pu}$ line at $300.057 \mathrm{~nm}$.

To test the validity of the method developed, we compared the ICP-AES results with those obtained by the liquid scintillation technique and by potentiometry. The ${ }^{241}$ Am concentration in the samples was ascertained using $\gamma$-spectrometry. Due corrections were applied to calculate the net $\mathrm{Pu}$ amount after liquid scintillation measurements. The Pu concentrations obtained for plutonium in five synthetic samples by ICP-AES/ 


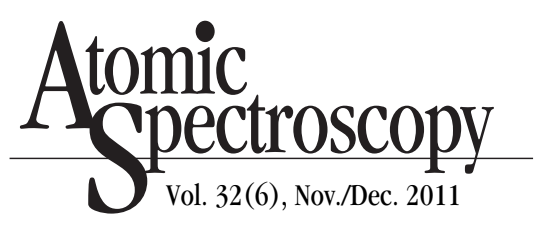

radiometry or potentiometry are given in Table VII. It should be noted that in the samples containing $\mathrm{mg}$ amounts of Pu only ICP-AES and the potentiometric technique could be employed since the radiometric method would involve very large dilutions. The method described in this study was regularly employed to monitor the $\mathrm{Pu}$ concentration in the separated samples after its removal by solvent extraction and also in radioactive waste solutions generated in our laboratory.

\section{CONCLUSION}

In this study, plutonium (Pu) was determined by inductively coupled plasma atomic emission spectrometry (ICP-AES) in the range of $0.10-100 \mu \mathrm{g} / \mathrm{mL}$ using the 300.057 and $453.615 \mathrm{~nm}$ analytical lines. The detection limit obtained for $\mathrm{Pu}$ is, respectively, $30 \mathrm{ng} / \mathrm{mL}$ (for $300.057 \mathrm{~nm}$ ) and $70 \mathrm{ng} / \mathrm{mL}$ (for $453.615 \mathrm{~nm}$ ). To test the accuracy, the results obtained by ICP-AES were compared with those obtained by radiometric and titrimetric methods. At lower concentration levels, ICP-AES showed better precision compared to the radiometric method as the latter involves very large dilutions. However, at higher concentration levels ( $\geq 1 \mathrm{mg}$ ), the titrimetric method scored over ICP-AES in terms of precision. The inter-element correction studies show that the Pu line at $453.615 \mathrm{~nm}$ is less prone to spectral interference effects as compare to $\mathrm{Pu}$ at the $300.057 \mathrm{~nm}$ line. It is also clear that the analysis based on $\mathrm{Pu}$ at the $453.615 \mathrm{~nm}$ line is preferable in comparison to the analysis obtained with Pu at $300.057 \mathrm{~nm}$. However, this would be at the cost of an increased limit of quantification.

The method proposed is useful for the determination of $\mathrm{Pu}$ in aqueous waste solutions generated in radiochemical laboratories and also

TABLE VII

Comparison With Other Analytical Methods

\begin{tabular}{cccc}
\hline Sample & $\begin{array}{c}\text { ICP-AES } \\
(\mu \mathrm{g} / \mathrm{mL})\end{array}$ & $\begin{array}{c}\text { Radiometric } \\
(\mu \mathrm{g} / \mathrm{mL})\end{array}$ & $\begin{array}{c}\text { Titrimetry } \\
(\mu \mathrm{g} / \mathrm{mL})\end{array}$ \\
\hline S-1 & $0.5 \pm 0.13$ & $0.6 \pm 0.15$ & - \\
S-2 & $2.0 \pm 0.09$ & $2.2 \pm 0.32$ & - \\
S-3 & $10.0 \pm 0.08$ & $10.2 \pm 3.2$ & - \\
S-4* & $240.1 \pm 5.82$ & $235.2 \pm 20.21$ & - \\
S-5* & $1870 \pm 19.85$ & - & $1850 \pm 3.70$ \\
\hline
\end{tabular}

*Analyzed after dilution by ICP-AES/Radiometric techniques.

to monitor the trace levels of $\mathrm{Pu}$ left in the raffinate (after its separation with a suitable extractant) along with other metallic constituents.

\section{ACKNOWLEDGEMENT}

The authors are grateful to Dr. A. Goswami, Head, Radiochemistry Division, for his keen interest and encouragement in the course of this work. The authors are also thankful to Smt. S.K. Shiny for her help in the plutonium determination by potentiometry.

Received July 2, 2011.

\section{REFERENCES}

1. M.C. Edelson, AMES Laboratory, Iowa State University, Ames, $\mathrm{OH}$, USA, IA 50011, IS-5085, UC-2 (1992).

2. Mithlesh Kumar, M. Mohapatra, Paru J. Purohit, S.K. Thulasidas, T.K. Seshagiri, Neelam Goyal, and S.V.Godbole, At. Spectrosc. 31(3), 97 (2010).

3. A.A. Argekar, M.J. Kulkarni, J.N. Mathur, and A.G. Page Talanta 56, 591 (2002).

4. A. Sengupta, V.C. Adya, R. Acharya, P.K. Mohapatra, and V.K. Manchanda, J. Radioanal. Nucl. Chem. 287 (1), 281 (2011).

5.T.K. Seshagiri, Y. Badu, M.L. Jayanth Kumar, A.G.I. Dalvi, M.D. Sastry, and B.D. Joshi, Talanta 31, 773 (1984).
6. A.A. Argekar, M.J. Kulkarni, J.N. Mathur, and A.G. Page, Talanta 56, 591 (2002).

7. A. Sengupta, V.C. Adya, Mithlesh Kumar, S.K. Thulasidas, S.V. Godbole, and V.K.Manchanda, At. Spectrosc. 32(2), 49 (2011).

8. M.C. Edelson, E.L. Declab, R.K. Winge, and V.A. Fassel, Spectrochim. Acta 41B, 475 (1986).

9. E. Mainka, H.G. Muller, and F. Geyer, Document KfK 3578 (Kernforschungszentrum Karlsruhe, Institute for Radiochemie, Karlsruhe, Germany (1983).

10. E.A. Huff and D.L. Bowers, Appli. Spectrosc. 44, 728 (1990).

11. X. Claudon, J.C. Birolleau, M. Lavergne, R. Miche, and C. Bergey, Spectrochim. Acta 42B, 407 (1987).

12. M.J. Kulkarni, S.K. Thulasidas, N. Goyal, A.G. Page, and M.D. Sastry, Anal. Lett. 23(11), 2095 (1990).

13. Carmen S. Sabau, Delbert L. Bowers, and Florence P. Smith, ANL/CMT-ACL/CP-989869, CONF-9604136-10, Analytical Chem. Laboratory, Chemical Technology Division, Argonne National Laboratory, Argonne, IL, USA (1996).

14. V.C. Adya, S.K. Thulasidas, M. Kumar, P.J. Purohit, M. Mohapatra, T.K. Seshagiri, and S.V. Godbole, Radiochim. Acta 99, 1-5 (2011).

15. IUPAC, Appl. Spectrosc. 31, 348 (1977). 